\title{
14
}

\section{Muddy rivers and toxic flows: Risks and impacts of artisanal gold-mining in the riverine catchments of Bombana, Southeast Sulawesi (Indonesia)}

\section{Sara Beavis and Andrew McWilliam}

In 2008, the Bombana District (Kabupaten) of Southeast Sulawesi in eastern Indonesia experienced a dramatic influx of artisanal miners following the chance discovery of alluvial gold in the Tahe Ite and, later, Wumbubangka rivers (located in the sub-districts of Rarowatu and Rarowatu Utara, respectively). As stories of the golden bounty spread, a flood of gold prospectors arrived in the area, many of them opportunistic, temporary migrants from other regions in Indonesia, and began working the alluvial goldfields immediately adjacent to, and within, the river systems. Within months, there was said to be a 'sea of people' (lautan manusia) streaming into the area as thousands of hastily constructed prospecting camps sprung up along $15 \mathrm{~km}$ of the main channel of the Tahe Ite River and then expanded into other areas.

The initial reception of the artisanal mining was positive. The Governor of Southeast Sulawesi at the time was a strong promoter of mining development in the province, and declared the discovery a sign of the grace and blessing of Allah (rahmat dan berkah) (IKAPERMAB- 
Yogyakarta 2009). The local district head (bupati) issued a government regulation-Surat Keputusan No. 10, 2008-which decreed that the miners would have to pay as much as IDR250,000 (US\$24) per person in licensing fees to work the prospective sites (Kamil 2009). By mid-2009, according to news reports, there were approximately 60,000 gold panning licences issued and as much as IDR15 milliar (over US\$1.5 million) flowing into regional government coffers (IKAPERMAB-Yogyakarta 2009). At the same time, the local government also issued a series of formal exploration and mining licences (called Kuasa Pertambangan, KP; and, since 2009, Ijin Usaha Pertambangan, IUP) within their district jurisdiction to a growing number of gold exploration companies seeking to secure potentially lucrative leases.

The initial enthusiasm for mining activity, however, was soon tempered by a litany of problems and complaints that quickly emerged from the inadequate oversight and compliance monitoring of artisanal and smallscale mining (ASM). Among the impacts from the dramatic influx of artisanal miners was visibly increased river channel erosion and sediment loads from the finely sifted materials, described as a 'thick porridge' (bubur kental), which flowed downstream from the scattered diggings in the riverbed. Damage to roads was readily apparent as monsoon rains turned dirt tracks into impassable bogs, and conflict with local villagers expanded over access and use of customary lands, extensive illegal logging and disruption of river flows downstream extending to neighbouring settlements. Downstream rice farmers in villages utilising the Langkowala River, for example, reported major declines in water supply for irrigation. Finally, a growing number of artisanal prospectors had died in their attempts to excavate gold ore from the narrow tunnels and deep holes (lubang tikus) dug into the river channels (Kamil 2009), and there were reports of an increase in a variety of social ills, such as prostitution, drunkenness, muggings and violence on the goldfields.

In response to the growing public outcry, the government implemented a series of quasi-effective crackdowns (police 'sweeping' operations) on mining activities, especially in relation to the proliferating unlicensed artisanal operations (known as penambang tanpa injin, PETI). Their attempts to reduce and regulate the influx of people seeking good fortune (rezeki) from gold planning had some initial success. But, in the chaotic circumstances, many commentators and reporters of the unprecedented developments in Bombana questioned whether the golden bounty was really a blessing or a disaster for the general community. 
Sahrul, representing the advocacy non-government organisation Sagori, which has protested against the destructive impact of mining in the region, argued that mining really only benefited a few and was simply an 'ATM' for the benefit of certain government and security authorities, while local people were marginalised in the process (Antara 2012).

\section{Anatomy of a gold rush: Hidden risks}

Integral to artisanal gold-mining in the region has been the widespread and sustained use of elemental mercury for processing the gold. This practice has resulted in extensive, unregulated releases of mercury into the river systems that support valuable downstream land and riverine activities, including irrigation, tambak fish ponds and estuarine fishing. Seven years on since the first discoveries of alluvial gold, the active mining population has reduced substantially as a result of declining gold yields and greater government control over licensing and access for authorised mining companies. But even as the intensity of the gold rush has diminished, continuing hydraulic mining of the riverbanks and channels has left a long-lasting deleterious environmental legacy. In previously worked areas, there is an extensive accumulation of unprotected mine tailings and drainage pits, within and adjacent to streams and waterways. Downstream flows in the two affected river catchments still exhibit regular, extreme levels of turbidity and sediment loads - a result of the intensive mining of riverbanks and beds in the upper catchments, in combination with heavy seasonal monsoon rains.

This chapter reflects on the initial results of a targeted sampling program of river water and sediments at key points of the Langkowala and Kasetahi river systems during the year 2015 (Figure 14.1). The sampling was undertaken, in part, as a training exercise with selected staff drawn from regional government environmental agencies and university staff, and as a demonstration of the value of scientific analysis and monitoring to facilitate and support public policy debate and planning. The survey was complemented with a social mapping exercise to better understand human-water interactions and experiences along the river channels. Here, we consider both the immediate impacts and implications of the downstream effects of mining, as well as the longer-term risks and environmental management challenges of the riverine environments for the thousands of residents and artisanal miners who derive livelihoods from their flows. 
The research forms part of a three-year Australian Government funded project entitled, Artisanal and Small Scale Mining for Development (eastern Indonesia) (2014-2017). It brought together Australian and Indonesian research partners in a project designed to strengthen social and environmental impact assessment methodologies, and to improve policy aspects of mining governance in the region.

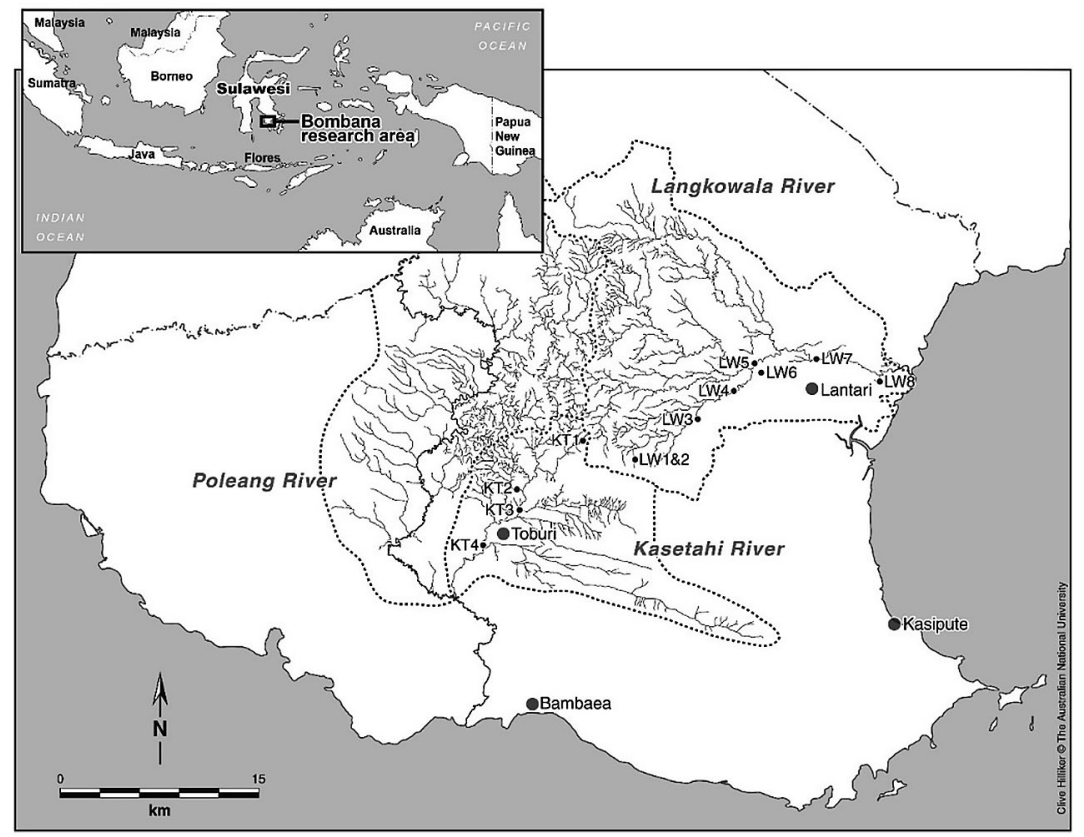

Figure 14.1: Location of study area and sampling sites

Source: Clive Hilliker @The Australian National University.

\section{The mercury cycle and its pathways}

Mercury is widely used in artisanal gold-mining to facilitate gold processing through the chemical bonding of gold and mercury to form an amalgam. The mercury is then removed through the application of heat (either by direct flame or retorting). However, the process is highly toxic and its indiscriminate use is associated with deleterious environmental and public health risks. In Bombana, as in most other small-scale goldmining sites around the world where the unregulated use of mercury is widespread, local ignorance and disregard of mercury's toxicity and potential harm is commonplace. 
By way of overview, mercury is also added to the environment from natural sources (for instance, degassing from soil and water, volcanic eruptions, fire, weathering of mercury-bearing rock), as well as anthropogenic sources (for instance, mining, industry, cremations). It is cycled through the atmosphere and lithosphere, and can be converted to a more soluble and volatile organic form known as methyl mercury by biologically mediated processes within the soil and water, or once ingested by organisms (for example, within the rumen of cattle or the muscle of fish). Mercury is readily taken up by organisms and it bio-accumulates over time; the longer the exposure to mercury, the higher the risk (Lechler et al. 2000; Limbong et al. 2003).

Mercury also bio-magnifies as a step-by-step process along the food chain (Veiga et al. 1999; Limbong et al. 2003). Top-level predators are therefore particularly vulnerable to the accumulated effects of mercury contamination within the environment. For people living and working in a mercury-contaminated setting, such as artisanal small-scale goldmining, the pathways that mercury can take are various. They include inhalation of vaporised mercury released during torching of the mercurygold amalgam; ingestion of contaminated water and food; and direct skin contact with contaminated water, sediment, soil and gold amalgam (van Straaten 2000a, 2000b; Cortes-Maramba et al. 2006; Kitula 2006). Importantly, mercury not only passes the blood-brain barrier, but also through breast milk and the placenta. Unborn foetuses and young babies are therefore at significant risk if their mothers have been exposed to mercury. The risk to individuals varies according to the form of mercury (whether inorganic or organic), the pathway of uptake and the length and magnitude of exposure. In the district of Bombana, risks are mainly associated with inhaling vaporised mercury through the process of unprotected burning of amalgam, drinking contaminated water and having direct skin contact with mercury or contaminated water during mining operations.

\section{Mercury sampling in Bombana, 2015}

In considering the impact of mercury released into the environment, it is well attested in global literature that one of the most direct and dangerous interactions with mercury is through the burning of amalgam to isolate gold (Bank 2012). As part of our collaborative research activities in Bombana, the project is working with an non-government organisation anti-mercury advocacy group, BaliFokus, to highlight public health risks 
and effects from direct contact with mercury. ${ }^{1}$ As part of their activities, BaliFokus has undertaken mercury vapour analysis at a range of locations in the study area, with some striking results. Levels of airborne mercury were recorded in a variety of locations within the active residential mining areas of Wumbubangka Village (Langkowala catchment) and Rau Rau Village (Kasetahi catchment). These results are shown in Table 14.1. The findings reveal a wide range of concentrations across locations with the highest values at four specific sites that are well above US-determined safe levels of exposure. These sites are mainly local shops (toko) that trade in gold and are likely to be places where mercury is volatised through burning. When these activities are undertaken in enclosed spaces with little ventilation, dense mercury vapour may linger in the air and expose the occupants to increased mercury inhalation and ingestion. Occupants in these contexts include women of the household, who may combine amalgam-processing with nurturing care of infants. Sustained exposure to these levels of mercury vapour can lead to severe lung damage, neurological problems, tremors, skin rashes, ataxia, insomnia and kidney abnormalities (McKelvey and Oken 2012).

Table 14.1: Concentrations of airborne mercury in the Kasetahi and Langkowala catchments, Bombana District, South East Sulawesi

\begin{tabular}{|c|c|c|}
\hline \multicolumn{3}{|l|}{ Mercury ambient emission sampling, Bombana, March 2015} \\
\hline Sampling point & Area & $\mathrm{Hg}\left(\mathrm{ng} / \mathrm{m}^{3}\right)$ \\
\hline Toko klontong/emas Resky (shop) & SP2 & $3,196.91$ \\
\hline Rumah Ibu Niartini (private dwelling) & Watu-Watu & n/a \\
\hline Toko emas (gold shop) & Wumbu Bangka & 287.58 \\
\hline Toko emas Pak Salam (Toko Obat 99) (gold shop) & Wumbu Bangka & $54,931.84$ \\
\hline Toko Pulsa Ibu Wira/Pak Yasin (shop) & Wumbu Bangka & $13,118.07$ \\
\hline Toko emas Misan (yard of gold shop) & Wumbu Bangka & 303.76 \\
\hline Toko emas Misan (gold shop near site of amalgam burning) & Wumbu Bangka & $17,363.23$ \\
\hline Restan (near site of amalgam burning) & Wumbu Bangka & $6,532.08$ \\
\hline Toko emas Pak Andika (gold shop firebox) & Wumbu Bangka & $1,363.75$ \\
\hline Ruang tengah Pak Andika & Wumbu Bangka & $6,246.60$ \\
\hline Tempat pembarakan Pak Andika (amalgam burning site) & Wumbu Bangka & $27,210.71$ \\
\hline Rumah Suci (private dwelling) & Wumbu Bangka & 258.81 \\
\hline Rumah Pak Pere (private dwelling) & Rau-Rau & 32.69 \\
\hline Rumah Dita (private dwelling) & Rau-Rau & 28.07 \\
\hline
\end{tabular}

Note: $\mathrm{Hg}$ = mercury; SP2 = identifier for a specific transmigration settlement.

Source: Field survey data provided by BaliFokus, 2015

1 BaliFokus has also been working with local public health service providers (Depkes) to raise awareness of environmental mercury applications and their potential human health risks. To date, the Indonesian health system has not developed any effective public health campaigns around mercury toxicity and artisanal gold-mining, despite its widespread distribution across Indonesia and demonstrated deleterious health impacts for people closely involved in the practice (see, for example, Limbong et al. 2003; Global Mercury Project 2006; Serikawa et al. 2011). 
In order to determine the concentration of mercury in the river systems affected by mining, samples of water and streambed sediments were collected at four sites along the Kasetahi River and eight sites along the Langkowala River. A background reference site sample was also taken from a stream within the boundaries of the neighbouring Rawa Aopa Watumohai National Park to the north where no mining activities occur. All samples were analysed for dissolved and total mercury.

Findings for dissolved mercury in the river samples were all below detection limits. This indicates that mercury in the river channel is adsorbed into, and forms fine coatings on, suspended particulate matter (for example, clay particles, organic matter and colloidal material) that subsequently settle out as stream velocity slows. Figures 14.2 and 14.3 show the concentrations of total mercury at the sampling sites, with reference to international and/ or national water- and sediment-quality guideline values for drinking water, aquatic ecosystem health, aquaculture and recreation (WHO 2011; ANZECC 2000; Canadian Council of Ministers of the Environment 1995). At the time of sampling, it was evident that more active mining was taking place within the Kasetahi catchment than the Langkowala, and this is reflected in the data; for example, the volumes of suspended sediment being transported by stream flow are shown in Figure 14.4. The results reflect the level of disturbance and the consequent mobilisation of materials off-site by the action of flowing water. Two sites on the Kasetahi River (KT2 and KT3) are characterised not only by the highest suspended sediment concentrations, but also of total mercury, with water- and sediment-quality guideline values for multiple uses being well exceeded. By contrast, the lower concentrations of mercury in the Langkowala River (LW1-8) can be attributed to less active mining at the time of sampling, and the dilution effects of tributary inflows. Nevertheless, water- and sediment-quality guidelines have also been exceeded at a number of sites along this river system.

Interestingly, although mercury is being added to the system, there are two sites on the Langkowala River (LW4 and LW7) where mercury is depleted, relative to the top of the catchment above the mining area. These sites are (i) immediately below a small irrigation dam, where heavy material will tend to fall out of suspension and be trapped behind the dam wall, depleting waters immediately downstream of particulates; and (ii) the site of river dredging, where coarse river sand is being removed from the stream for industrial use.

Figure 14.4 illustrates the variable suspended sediment concentrations in the two rivers and highlights the different conditions prevailing during sampling. As noted earlier, at the time there was significant alluvial 
and hydraulic mining being undertaken in the upper catchment of the Kasetahi, and river flow was visibly turbid. By contrast, in the Langkowala, where such activity was not apparent, the water was less turbid and this is reflected in the low concentrations of suspended sediment.

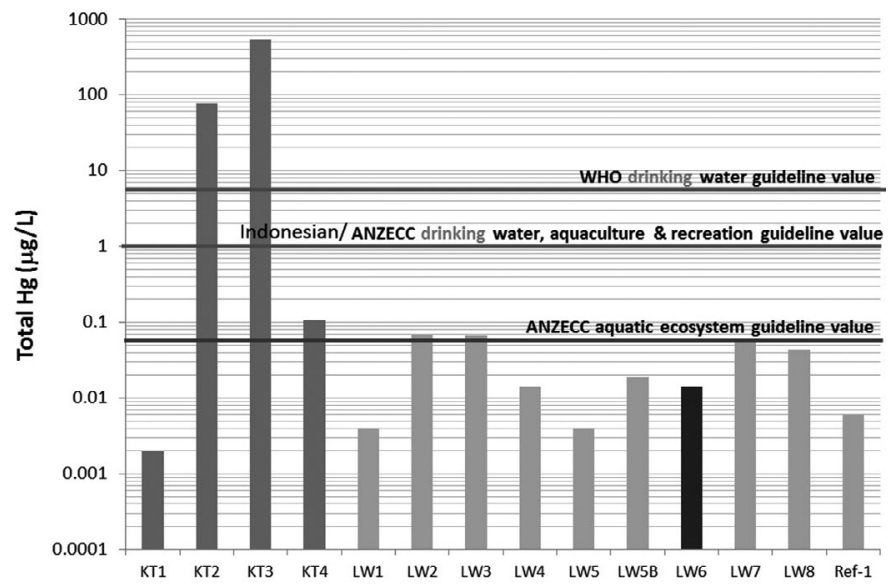

Figure 14.2: Concentrations of total mercury in stream waters of the Kasetahi and Langkowala rivers

Note: $\mathrm{KT}=$ Kasetahi River samples; $\mathrm{LW}=$ Langkowala River samples; $\mathrm{WHO}=$ World Health Organization (2011); ANZECC = Australian and New Zealand Environment Conservation Council (2000); Hg = mercury. Site LW6 refers to groundwater sampled from a village well; site Ref- 1 is the reference site outside of the two catchments.

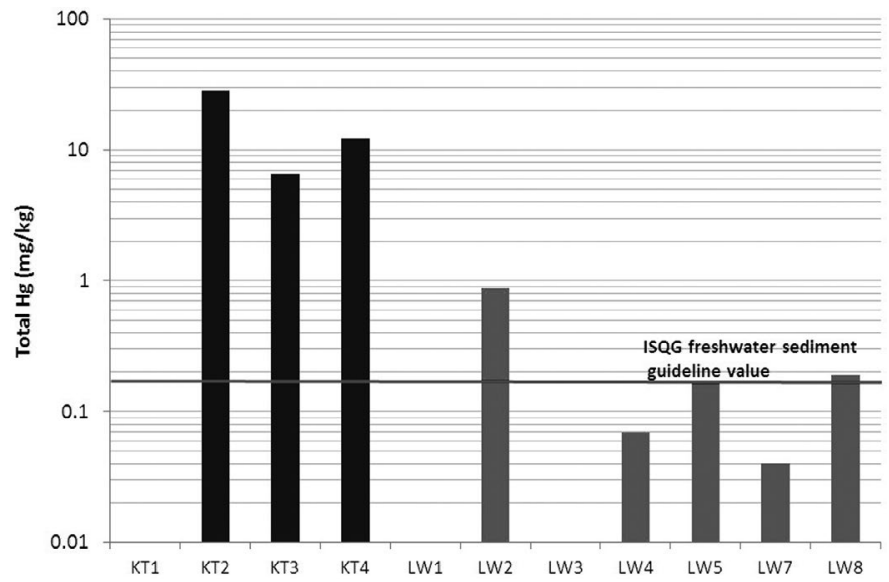

Figure 14.3: Concentrations of total mercury in the bed sediments of the Kasetahi and Langkowala Rivers

Note: KT = Kasetahi River samples; LW = Langkowala River samples; ISQG = International Sediment Quality Guideline; Hg = mercury. 


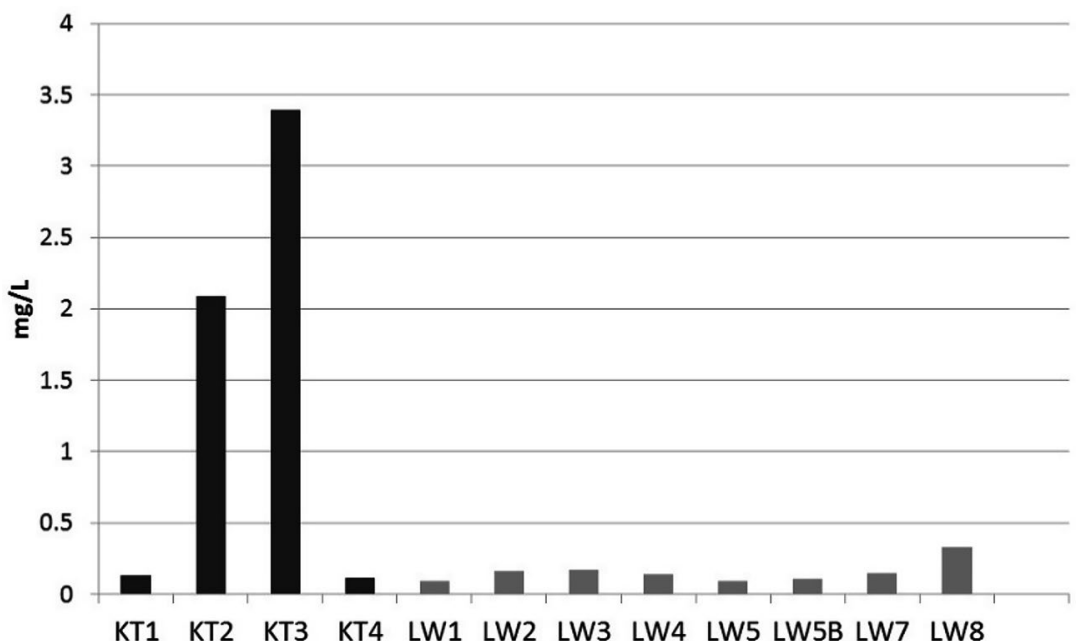

Figure 14.4: Concentrations of suspended sediment in waters of the Kasetahi and Langkowala rivers

Note: KT = Kasetahi River samples; LW = Langkowala River samples.

The monitoring results demonstrate that mercury is being added to the system and that the location and intensity of mining activity are playing key roles in the spatial patterns of contamination. This is consistent with findings in the broader literature (Gray et al. 2000; van Straaten 2000a, 2000b; Fadini and Jardim 2001; Roth et al. 2001). However, the concentrations of mercury in the water and sediments are not extremely high. This finding is likely to be a function of sampling in the middle of the dry season, when surface run-off and stream flow are relatively low. Seasonality is recognised as a salient factor in determining stream pollutant loads; in this case, sampling took place immediately after the fasting month of Ramadhan, when mining had generally ceased for the Idul Fitri/ Lebaran holiday. One of the preliminary results of this study, therefore, suggests that the contaminant concentrations observed in the river channels represent a current, best-case scenario. Higher concentrations of mercury, with associated risks, can be expected during the wet season and particularly in the first flushing events, when materials accumulated from mining over the dry season are mobilised and transported downstream. 


\section{Social mapping of human-water interactions}

Water and sediment sampling and analysis in the Bombana District has provided an initial, objective snapshot of unregulated mercury contamination and potential risks to human and environmental health in the region. As part of the collaborative research engagement established under the auspices of the project collaborative activities with the University of Halu Oleo and local government staff, field research extended to a social mapping exercise in the two mining-affected river catchments of Bombana. The survey sought to gather information of the nature and scope of human-water interactions in the riverine environments of the Kasetahi or Poleang and Langkowala rivers that are subject to the mercury contamination outlined in the foregoing section. An initial iteration of the social mapping was undertaken in July 2015 and involved visiting a number of locations along the river channels-from the top of the catchments (bulu) to the river mouths (bilir), observing conditions at these locations and more or less randomly interviewing local residents about their use of the river water, their observations and experiences of river flows since the onset of mining upstream.

Large numbers of residents and temporary or recent migrants live along the key river channels of the Kasetahi and Langkowala rivers, and have in the past drawn on the benefits of the river flows for many daily household activities. Water for household consumption and broader productive livelihood activities has long attracted farmers to the region. This range of interactions includes, for example, fresh water for consumption and domestic use (bathing, washing clothes), as well as places where children might play in the riverbeds and channels.

River water is also used widely for irrigation purposes-principally for irrigated rice (sawah) on the fertile sloping mid-catchment and plains of both river valleys, but also for line and net fishing and harvesting freshwater prawns downstream, for stocking fishponds and watering wandering livestock (Bali banteng cattle in particular), as well as a resource for hand-watering vegetable gardens, establishing fruit trees and for washing vehicles. There are established sites for seasonal sand mining from deposition of material in the riverbeds and for use in house construction and building, as well as water for cement mixing and much else. 
While the implementation of this social mapping exercise remains at an early stage, the responses of households living along the rivers were highly consistent and generally dissatisfied with the present condition of the rivers. Based on initial discussions and brief interviews with a range of respondents, there was a consensus view that there had been major and long-lasting negative impacts as a direct result of the enthusiastic but poorly regulated mining practices in the upper catchments.

Among the issues raised by respondents living and working in villages and townships along the main river channels was the widespread complaint that the river no longer provided a plentiful supply of potable water. These days, and for a number of years, following the advent of mining in the upper catchment, river quality has dropped dramatically and the flows are often very turbid or muddy (keruh), especially following rains. The situation is such that many respondents no longer draw on the river water for their household consumption, only using it when alternatives are not available, and even in these circumstances they will draw water selectively, when flows are visibly clearer. Most rely instead on a combination of nearby alternative spring water sources, limited government-provided reticulated water supply services and the purchase of potable water from mobile traders in the form of large plastic containers known as galon. The latter has become a regular feature of daily life in the goldfields area, and one that substantially increases living costs for householders and miners alike.

Another significant deleterious impact from hydraulic mining of riverbanks and beds, particularly in the Langkowala catchment, has been the disruption of river flows to substantial areas. Rice farmers in downstream villages of the Langkowala River, for example, reported major declines in water supply for irrigation, reducing land under production by nearly $500 \mathrm{ha}$, or the equivalent of 2,500 $\mathrm{t}$ of harvested rice (based on average yields of 4-5 t/ha), and considerably higher in terms of opportunity costs over time. Despite protests by farmers and farmer groups about the threat to their livelihoods as a result, little corrective action was taken by the local government. Consequently, many farmers who formerly relied on gravitational river flows have now switched to shallow pump well irrigation methods to ensure adequate supplies of water at critical times. The availability of groundwater resources has helped cushion the damaging impacts of mining, but has resulted in higher investment costs for farm inputs. Any impacts on groundwater resources from this increased use are not known. 
A third impact of the dramatic rise in river sediment flows and increased deposition of sediments in the river channels over recent years is the perceived higher incidence of localised flooding. Inundation of maturing cereal crops (especially rice and maize) with mud slurries can result in major crop losses for farmers cultivating crops adjacent to the river channels.

In the course of the social mapping exercise, participants visited a series of locations throughout the two catchments. The responses recorded were remarkably consistent in recognising the much-reduced water quality and heavy sediment loads during periods of active mining. At the mouth of the Langkowala River, a visit was made to a group of fishing households who have for many years fished (ikan bilang) and trapped river prawns (balachan). At Tanjung Baropa, a series of stilt and platform houses hug the southern bank and provide a staging base for working and managing a series of lift net (togo) structures erected in the main river channel.

Discussions with the group revealed a litany of complaints about the changing conditions of the river that they have been relying on for their livelihoods. They highlighted the heavy sediment loads deposited in the river mouth, which they attribute directly to the upstream mining activity. This has caused silting in the river mouth, preventing access to larger trading boats that used to purchase their catch on a regular basis. The traders are now forced to anchor further out and require the fishers to use their own boats to make an additional transfer of their catch. The fishing households have also observed declining yields from their fishing efforts, which they attribute to the turbidity of sediment loads in the river flows, reduced flows at times ${ }^{2}$ and the frequent flooding after rains in the upper catchment, which damages their lift nets and reduces their ability to sustain productive yields. In these and other ways, a highly sustainable and low-impact fishery that has flourished for years is now under threat from the disregard and neglect of environmental standards, and the absence of effective artisanal mining procedures.

2 Fishing households also blame the upstream fish pond (tambak) operators who hold back water in their retention ponds at low tide. 


\section{Conclusions}

Artisanal mining in the Bombana district of Southeast Sulawesi and its downstream effects are strikingly evident in the quality of water and sediments examined in this study. Through targeted water and sediment sampling at different locations in the river systems, we can see what is being added to the system over time. We can also see how these impacts are modified by their dynamic interaction within the riverine systems. Test results reveal how and where mercury-contaminated particulates are trapped or removed from a stream. The pattern of mining intensity also influences how the contaminant concentration varies over time and space within waterways (for instance, during the Ramadhan fasting month), as does the seasonal pattern of monsoon rainfall, where the onset of the wet season has a flushing effect on river sediments and the mercury load that they carry. Identifying hotspots of contamination provides insight into the risks of exposure, for both people and aquatic ecosystems.

Preliminary results drawn from this study suggest that the risks of mercury suspended in river water downstream of mining activity occur at a whole-of-river scale. The transport of mercury within the water column, mainly adsorbed into particulate matter, creates risks for biota (especially catfish, freshwater shrimp, etc.) to take up mercury along the river course. The long-term direct and cascading effects of mercury ingestion within these catchments remain unclear without further research. The results of the sampling survey thus illustrate the need for active and longer-term monitoring of river and sediment quality as an important environmental and public health initiative by local government. Continuing efforts of the research partners to promote and support policy initiatives directed to these ends form an integral part of the action research objectives of the present project.

Finally, the complementary social mapping survey into human-water interactions along the mining-affected river systems has highlighted a series of adverse environmental and ecological impacts from the massively increased sediment flows due to unregulated hydraulic mining of riverbeds and banks. In particular, damage and destruction to the river amenity and its associated high-value, downstream benefits for local communities and rural livelihoods is a major and unfortunate legacy of artisanal mining. It is by no means evident that the short-term and limited economic benefits of the Bombana gold rush offset the long-term environmental costs that are borne by the majority of residents. 


\section{References}

Antara, 2012. 'Tambang: LSM minta Pemda Bombana moratorium izin tambang.' 17 February. Viewed at www.bisnis-kti.com/index.php/ 2012/02/tambang-lsm-minta-pemda-bombana-moratorium-izintambang/ (site discontinued)

Australian and New Zealand Environment Conservation Council (ANZECC), 2000. Australian and New Zealand Guidelines for Fresh and Marine Water Quality_Volume 1: The Guidelines. Canberra, ACT: Australian and New Zealand Environment and Conservation Council, and Agriculture and Resource Management Council of Australia and New Zealand.

Bank, M.S. (ed.), 2012. Mercury in the Environment: Pattern and Process. Berkeley: University of California Press. doi.org/10.1525/ california/9780520271630.001.0001

Canadian Council of Ministers of the Environment, 1995. Protocol for the Derivation of Canadian Sediment Quality Guidelines for the Protection of Aquatic Life. CCME EPC-98-E. Ottawa: Environment Canada, Guidelines Division, Technical Secretariat of the CCME Task Group on Water Quality Guidelines.

Cortes-Maramba, N., J.P. Reyes, A.T. Francisco-Rivera, H. Akagi, R. Sunio and L.C. Panganipan, 2006. 'Health and Environmental Assessment of Mercury Exposure in a Gold Mining Community in Western Mindanao, Philippines.' Journal of Environmental Management 81: 126-34. doi.org/10.1016/j.jenvman.2006.01.019

Fadini, P.S. and W.F. Jardim, 2001. 'Is the Negro River Basin (Amazon) Impacted by Naturally Occurring Mercury?' Science of the Total Environment 275: 71-82. doi.org/10.1016/S0048-9697(00)00855-X

Global Mercury Project, 2006. 'Environmental and Health Assessment Report: Removal of Barriers to the Introduction of Cleaner Artisanal Gold Mining Extraction Technologies. Brazil, Indonesia, Laos, Sudan, Tanzania Zimbabwe.' Global Environment Facility, United Nations Development Programme, United Nations Industrial Development Organization. 
Gray, J.E., P.M. Theodoraka, E.A. Bailey and R.R. Turner, 2000. 'Distribution, Speciation and Transport of Mercury in Stream Sediment, Stream Water and Fish Collected near Abandoned Mines in South Western Alaska, USA.' Science of the Total Environment 260: 21-33. doi.org/10.1016/S0048-9697(00)00539-8

IKAPERMAB-Yogyakarta, 2009. 'Bombana dpt Lailatur Qadr.' 15 September. Available at ikapermab-yogyakarta.blogspot.com.au/ 2009/09/bombana-dpt-lailatur-qadr.html

Kamil, S.Y., 2009. 'Tambang Emas Bombana: Berkah Atau Ancaman?' Sagori Hijau Indonesia, 23 July. Viewed at sarekathijauindonesia. org/2009/07/107.html (site discontinued)

Kitula A.G.N., 2006. 'The Environmental and Socio-economic Impacts of Mining on Local Livelihoods in Tanzania: A Case Study of Geita District.' Journal of Cleaner Production 14: 405-14. doi.org/10.1016/j. jclepro.2004.01.012

Lechler, P.J., J.R. Miller, L.D. Lacerda, D. Vinson, J.C. Bonzongo, W.B. Lyons and J.J. Warwick, 2000. 'Elevated Mercury Concentrations in Soils, Sediments, Water and Fish of the Madeira River Basin, Brazilian Amazon: A Function of Natural Enrichments?' Science of the Total Environment 260: 87-96. doi.org/10.1016/S0048-9697(00)00543-X

Limbong, D., J. Kumampung, J. Rimper, T. Arai and N. Miyazaki, 2003. 'Emissions and Environmental Implications of Mercury from Artisanal Gold Mining in North Sulawesi.' Science of the Total Environment 302: 227-36. doi.org/10.1016/S0048-9697(02)00397-2

McKelvey, W. and E. Oken, 2012. 'Mercury and Public Health: An Assessment of Human Exposure.' In M.S. Bank (ed.), Mercury in the Environment: Pattern and Process. Berkeley and Los Angeles: University of California Press. doi.org/10.1525/ california/9780520271630.003.0013

Roth, D.A., H.E. Taylor, J. Domagalski, P. Dileanis, D.B. Peart, R.C. Antweiler and C.N. Alpers, 2001. 'Distribution of Inorganic Mercury in Sacramento River Water and Suspended Colloidal Sediment Material.' Archives of Environmental Contamination and Toxicology 40(2): 161-72. doi.org/10.1007/s002440010159 
Serikawa, Y., T. Inoue, T. Kawakami, B. Cyio, I. Nur and E. Elvince, 2011. 'Emission and Dispersion of Gaseous Mercury from Artisanal Small-Scale Gold Mining Plants in the Poboyu Area of Palu City, Central Sulawesi, Indonesia.' Paper presented at the 10th International Conference on Mercury as a Global Pollutant, Halifax, Nova Scotia, Canada, July.

van Straaten, P., 2000a. 'Human Exposure to Mercury due to Small Scale Gold Mining in Northern Tanzania.' Science of the Total Environment 259: 45-53. doi.org/10.1016/S0048-9697(00)00548-9

van Straaten, P., 2000b. 'Mercury Contamination Associated with Small Scale Gold Mining in Tanzania and Zimbabawe.' Science of the Total Environment 259: 105-13. doi.org/10.1016/S0048-9697(00)00553-2

Veiga, M.M., J. Hinton and C. Lilley, 1999. 'A Comprehensive Review with Special Emphasis on Bioaccumulation and Bioindicators.' Proceedings of National Institute for Minamata Disease, Japan, pp. 19-39.

World Health Organisation (WHO), 2011. Guidelines for DrinkingWater Quality. 4th edition. Geneva: WHO. Available at apps.who.int/ iris/bitstream/10665/44584/1/9789241548151_eng.pdf 
This text is taken from Between the Plough and the Pick: Informal, artisanal and small-scale mining in the contemporary world, edited by Kuntala Lahiri-Dutt, published 2018 by ANU Press, The Australian National University, Canberra, Australia.

doi.org/10.22459/BPP.03.2018.14 